\title{
The Use of Bean Sprout Extract as Supplement for the Growth of Plaintain Unti Sayang (Musa paradisiaca L.) by Tissue Culture
}

\author{
Nirwana Jufri \\ Faculty of Agriculture. Indonesian Muslim University-Makassar, Indonesia
}

Abdullah

Faculty of Agriculture. Indonesian Muslim University-Makassar, Indonesia

Devi Susanti

Faculty of Agriculture. Indonesian Muslim University-Makassar, Indonesia

\author{
Received: November 2, 2013 Accepted: November 20, 2013 \\ doi:10.5296/jas.v2i1.5137 URL: http://dx.doi.org/10.5296/jas.v2i1.5137
}

\begin{abstract}
One of the problems in plaintain development is on the plant breeding that has been conducted convensionally by using seedlings, so that it requires time and wide field, different treatment, and potentially brings pests and deseases. The bean sprout extract is potentially useful in improving the explant growth quality of plaintain by tissue culture. This study aims to know the influence of bean sprout extract concentration as supplement in tissue culture media upon the explant growth of plaintain Unti sayang (Musa paradisiaca $\mathrm{L}$ ). There are 4 dosages of bean sprout extract as control. The data was analyzed by using ANOVA and was continued by using BNJ test. The result of the experiment shows that the bean sprout extract influences significatly on the plantlets height, leaf number, root length, and root number. The dosage of $100 \mathrm{~g} / \mathrm{l}$ and $200 \mathrm{~g} / \mathrm{l}$ bean sprout extracts provide the best result on the experimenting component of plantlet height, leaf number, root length, and root number. Meanwhile, the experimenting component of leaf number and the wet weight of the plantlets provide the best result on MS without any addition of bean sprout extract.
\end{abstract}

Keywords: Plaintain Musa paradisica L, Tissue culture, Bean sprout culture, Murashige and Skoog Media 


\section{Introduction}

Plaintain Unti sayang (Musa paradisica L.) has a very important role in Indonesia since it is the most consuming fruits, compared to the others. In addition, plaintain has also multifunction since almost all of its parts can be used. For example, the inflorence can be used as vegetable, the leaves can be used as wrapper of traditional cakes, the pseudo-stem can be used as chips, the skin can be used to make vinegar through fermentation process and to be yogurt raw material, the stem can be used as the cattle foods, compost material, and also it can be processed to be fiber for clothes and paper (Rosdiana, 2009)

The breeding of banana was conducted convensionally by using seedling, namely by slicing the seedlings that have two to three buds. However, breeding by using this technique generally needs a quite long time, wide field, created differently, and potentially brings pests and deseases. Thus, it then becomes the problem in the banana development. Therefore, tissue culture was conducted to get more effective result in the breeding process in order to produce more quality seeds in a greater number. Wetherell (1982) said that this breeding technique is also called as in vitro, in which every cell is able to grow to be a new individual.

The growth of the plant parts in tissue culture are significantly influenced by the type of media and components inside (Thymann, 1935). (Gunawan, 1998). In the previous study, the use of bean sprout extract could stimulate orchid more optimally compared to the growth of orchid without bean sprout extract (Soreyowinoto and Moeso, 1977). According to Amaliah and Astuti (2006) and USDA (2009), bean sprout extract contains vitamin and mineral such as vitamin C, Thiamin, Riboflavin, Niasin, Vitamin B, $\beta$-karotein, Vitamin A, and Vitamin E. whereas, mineral contained in bean sprout are Calsium $(\mathrm{Ca})$, Ferro $(\mathrm{Fe})$, magnesium $(\mathrm{Mg})$, phosphor $(\mathrm{P})$, sodium $(\mathrm{Na})$, zink $(\mathrm{Zn})$, tembaga $(\mathrm{Cu})$ dan mangan $(\mathrm{Mn})$. Based on the vitamin and mineral content in the bean sprout extract, it is potentially used in the growth of the plaintain explant by tissue culture.

\section{Method of the Study}

This study was conducted in Tissue Culture Laboratorium Instalation of Regional Duties Implementation Unit, Holticultural Breeding Centers, Agriculture Department of Corps and Holtoculture of Sout Sulawesi Province, in February 2012 to May 2012. The planting material used was plaintain inoculum $M$. paradisica $L$. the product of sub culture of 6-month-old bid. The laboratorium study used Completely Randomized Design (CRD) with three times repititions for each treatment. The data resulted was analyzed by using F 0.05 and 0.01 tests; also BNJ 0.05 test to differenciate the treatments.

The study was conducted in several stages continuously, including sterilizing tools and material, formulating stock liquid, formulating bean sprout extract, making media and planting inoculum. This study used basic formulation of MS (Murashige and Skoog) Media with the treatments: MS without adding bean sprout extract (control), $\mathrm{MS}+50 \mathrm{~g} / \mathrm{l}$ bean sprout extract, $\mathrm{MS}+100 \mathrm{~g} / \mathrm{l}$ bean sprout extract, MS $+150 \mathrm{~g} / \mathrm{l}$ bean sprout extract, and MS + $200 \mathrm{~g} / \mathrm{l}$ bean sprout extract. The observation components in the age of 12, MST: plantlet height, leaf number, root length, and root number, and plantlet wet weight. 


\section{Result}

\subsection{Plantlet Height}

The result of observation of plantlet height average of 12 -week plaintain after planting is presented in Table 1. The analysis of variance shows that the treatment of bean sprout extract in every consentration influences significantly on F 0.01 test taraff on the plantlet height of the plaintain.

Table 1. The Plantlet Height Average $(\mathrm{cm})$ of the Plaintain of $M$. paradisica L. in week 12th after planting in Various Bean Sprout Extract.

\begin{tabular}{|l|c|c|c|}
\hline \multicolumn{1}{|c|}{ Treatment } & High Planlet $(\mathrm{cm})$ & $\sqrt{ } \mathrm{X}+0,5$ & NP BNJ 0.05 \\
\hline D0 = MS without the addition of bean sprouts extract & 5.39 & $2.43^{\mathrm{b}}$ & \\
D1 = MS + extract 50 g/l & 6.30 & $2.54^{\mathrm{b}}$ & \\
D2 = MS + extract 100 g/l & 15.30 & $3.94^{\mathrm{a}}$ & \multirow{2}{*}{1.111} \\
D3 = MS + extract 150 g/l & 11.48 & $3.45^{\text {ab }}$ & \\
D4 = MS + extract 200 g/l & 13.73 & $3.77^{\mathrm{a}}$ & \\
\hline
\end{tabular}

Information: The Average value that is followed by same letter is insignificantly different in BNJ 0.05 test taraff.

The result of BNJ in Table 1 shows that the highest average of plantlet height is obtained in the treatment of $\mathrm{MS}+100 \mathrm{~g} / \mathrm{l}$ bean sprout extract (D2), significantly different from the tratment of MS + $50 \mathrm{~g} / \mathrm{l}$ bean sprout extract (D1), and MS without addition of bean sprout extract (DO). However, it is insignificantly different with the treatment of MS + $150 \mathrm{~g} / \mathrm{l}$ bean sprout extract (D3) and MS + $200 \mathrm{~g} / \mathrm{l}$ bean sprout extract (D4).

\subsection{Leaf Lenght}

The result of observation data analysis of leaf length average of plaintain in week 12th after planting shows that the addition of bean sprout extract into cluture media significantly influences on F 0.05 test on the leaf length of the plaintain.

Table 2. The Leaf Length Average $(\mathrm{cm})$ of the Plaintain of $M$. paradisica L.in week 12th after planting in Various Bean Sprout Extract.

\begin{tabular}{|l|c|c|c|}
\hline \multicolumn{1}{|c|}{ Treatment } & Long Leaf $(\mathrm{cm})$ & $\sqrt{\mathrm{X}+0,5}$ & NP BNJ 0.05 \\
\hline D0 = MS without the addition of bean sprouts extract & 2.65 & $1.77 \mathrm{~b}$ & \\
D1 = MS + extract $50 \mathrm{~g} / \mathrm{l}$ & 2.89 & $1.80 \mathrm{~b}$ & \\
D2 $=$ MS + extract $100 \mathrm{~g} / \mathrm{l}$ & 6.84 & $2.69 \mathrm{a}$ & 0.835 \\
D3 = MS + extract $150 \mathrm{~g} / \mathrm{l}$ & 5.14 & $2.37 \mathrm{ab}$ & \\
D4 $=$ MS + extract $200 \mathrm{~g} / \mathrm{l}$ & 7.23 & $2.77 \mathrm{a}$ & \\
\hline
\end{tabular}

Information: The Average value that is followed by same letter is insignificantly different in BNJ 0.05 test taraff. 


\section{Ml Macrothink}

The result of BNJ 0.05 test on the leaf lenght of the plaintain in week 12th after plenting (Table 2) shows that the treatment of MS $+200 \mathrm{~g} / \mathrm{l}$ bean sprout extract (D4) provides the best and significant different from MS without addition of bean sprout extract (DO) and MS $+50 \mathrm{~g} / \mathrm{l}$ bean sprout extract (D1). However it is insignificantly different in the tratment of MS + $100 \mathrm{~g} / \mathrm{l}$ bean sprout extract (D2) and MS + $150 \mathrm{~g} / \mathrm{l}$ bean sprout extract (D3).

\subsection{Leaf Number}

The result of the observation of leaf number average of the plaintain in week 12th after planting is provided in Table 3.

Table 3. The Leaf Number Average of the Plaintain of $M$. paradisica L. in the age of week 12th after planting in Various Bean sprout Extract.

\begin{tabular}{|l|c|c|c|}
\hline \multicolumn{1}{|c|}{ Treatment } & $\begin{array}{l}\text { Number of } \\
\text { leaves }\end{array}$ & $\sqrt{ }$ X $+0,5$ & NP BNJ 0.05 \\
\hline D0 = MS without the addition of bean sprouts extract & 8.33 & $2.97^{\mathrm{a}}$ & \\
D1 = MS + extract $50 \mathrm{~g} / \mathrm{l}$ & 2.50 & $1.72^{\mathrm{c}}$ & \\
D2 = MS + extract $100 \mathrm{~g} / \mathrm{l}$ & 4.75 & $2.28^{\mathrm{b}}$ & 0.502 \\
D3 = MS + extract 150 g/l & 3.50 & $2.00^{\mathrm{bc}}$ & \\
D4 = MS + extract 200 g/l & 3.67 & $2.03^{\mathrm{bc}}$ & \\
\hline
\end{tabular}

Information: The Average value that is followed by same letter is insignificantly different in BNJ 0.05 test taraff.

The result of BNJ 0.05 test on the leaf number formed in week 12th after planting (Table 3) shows that MS without addition of bean sprout exstract (D0) indicates the most leaf number and insignificantly different from the tratment of $\mathrm{MS}+50 \mathrm{~g} / \mathrm{l}$ bean sprout extract (D1), MS + $100 \mathrm{~g} / \mathrm{l}$ bean sprout extract (D2), MS + $150 \mathrm{~g} / \mathrm{l}$ bean sprout extract (D3) and MS + $200 \mathrm{~g} / \mathrm{l}$ bean sprout extract (D4).

\subsection{Root Lenght}

The result of the observation of root lenght average of the plaintain $M$. paradisica L. in week 12th after planting is provided in Table 4. The analysis of variance shows that the treatment of bean sprout extract in every consentration influences significantly on F 0.01 test taraff on the root lenght.

Table 4. The Root Lenght Average (cm) of the Plaintain of M. paradisica L.in week 12th after planting in Various Bean Sprout Extract.

\begin{tabular}{|l|c|c|c|}
\hline \multicolumn{1}{|c|}{ Treatment } & The root length $(\mathrm{cm})$ & $\sqrt{ } \mathrm{X}+0,5$ & NP BNJ 0.05 \\
\hline D0 = MS without the addition of bean sprouts extract & 1.77 & $1.49^{\mathrm{b}}$ & \\
D1 = MS + extract 50 g/l & 3.66 & $2.02^{\mathrm{ab}}$ & \\
D2 = MS + extract 100 g/l & 7.50 & $2.76^{\mathrm{ab}}$ & 1.126 \\
D3 = MS + extract 150 g/l & 5.88 & $2.51^{\mathrm{ab}}$ & \\
D4 = MS + extract 200 g/l & 8.46 & $2.97^{\mathrm{a}}$ & \\
\hline
\end{tabular}




\section{Macrothink

Notes: The number that is followed by same letter is insignificantly different in BNJ 0.05 test.

The result of BNJ test in Table 4 shows that the longest root lenght average is obtained in the treatment of MS $+200 \mathrm{~g} / \mathrm{l}$ bean sprout extract (D4) and significantly different from MS without addition of bean sprout extract (DO). However it is insignificantly different in the tratment of $\mathrm{MS}+50 \mathrm{~g} / \mathrm{l}$ bean sprout extract (D1) and MS + $100 \mathrm{~g} / \mathrm{l}$ bean sprout extract (D2) as well as MS $+150 \mathrm{~g} / \mathrm{l}$ bean sprout extract (D3).

\subsection{Root Number}

The result of the observation of root number average of the plaintain in week 12th after planting is provided in Table 5. The analysis of variance shows that the treatment of bean sprout extract in every consentration influences significantly on F 0.01 test taraff on the plantlet root number formed.

Table 5. The Root Number Average $(\mathrm{cm})$ of the Plaintain of $M$. paradisica L. in week 12th after planting in Various Bean Sprout Extract.

\begin{tabular}{|l|l|l|l|}
\hline \multicolumn{1}{|c|}{ Treatmen } & number of Roots & $\sqrt{ } \mathrm{X}+0,5$ & NP BNJ 0.05 \\
\hline D0 = MS without the addition of bean sprouts extract & 1.67 & $1.42^{\mathrm{b}}$ & \\
D1 = MS + extract $50 \mathrm{~g} / 1$ & 1.67 & $1.46^{\mathrm{b}}$ & \\
D2 = MS + extract $100 \mathrm{~g} / 1$ & 4.42 & $2.20^{\mathrm{a}}$ & 0.742 \\
D3 = MS + extract $150 \mathrm{~g} / \mathrm{l}$ & 4.08 & $2.14^{\mathrm{a}}$ & \\
D4 = MS + extract $200 \mathrm{~g} / 1$ & 4.92 & $2.32^{\mathrm{a}}$ & \\
\hline
\end{tabular}

Information: The number that is followed by same letter is insignificantly different in BNJ 0.05 test taraff.

The result of BNJ test in Table 5 shows that the root number average is mostly obtained in the treatment of MS $+200 \mathrm{~g} / \mathrm{l}$ bean sprout extract (D4) and significantly different from MS without addition of bean sprout extract (D0). However it is insignificantly different in the tratment of $\mathrm{MS}+50 \mathrm{~g} / \mathrm{l}$ bean sprout extract (D1) and MS + $100 \mathrm{~g} / \mathrm{l}$ bean sprout extract (D3) as well as MS $+150 \mathrm{~g} / \mathrm{l}$ bean sprout extract (D3).

\subsection{Plantlet Wet Weight}

The result of the observation of plantlet wet weight average of the plaintain M. paradisica L. in week 12th after planting is provided in Table 6. The analysis of variance shows that the treatment of bean sprout extract in every consentration influences significantly plantlet wet weight. 
Table 6. The Plantlet Wet Weight Average (gram) of the Plaintain of M. paradisica L.in week 12th after planting in Various Bean sprout Extract.

\begin{tabular}{|l|l|l|l|}
\hline \multicolumn{1}{|c|}{ Treatmen } & Wet weight $(\mathrm{g})$ & $\sqrt{ } \mathrm{X}+0,5$ & NP BNJ 0.05 \\
\hline D0 = MS without the addition of bean sprouts extract & 2.83 & $1.81 \mathrm{a}$ & \\
D1 = MS + extract $50 \mathrm{~g} / 1$ & 0.61 & $1.04 \mathrm{~b}$ & \\
D2 = MS + extract $100 \mathrm{~g} / 1$ & 1.86 & $1.52 \mathrm{ab}$ & 0.57 \\
D3 = MS + extract $150 \mathrm{~g} / 1$ & 1.07 & $1.24 \mathrm{~b}$ & \\
D4 = MS + extract $200 \mathrm{~g} / 1$ & 1.45 & $1.39 \mathrm{ab}$ & \\
\hline
\end{tabular}

Information: The number that is followed by same letter is insignificantly different in BNJ 0.05 test taraff.

The result of BNJ 0.05 test on the plantlet wet weight of plaintain $M$. paradisica L. in week 12th after planting (Table 6) shows that MS without addition of bean sprout exstract (D0) provides the best influence and significantly different from the tratment of MS $+50 \mathrm{~g} / \mathrm{l}$ bean sprout extract (D1) and MS + $150 \mathrm{~g} / \mathrm{l}$ bean sprout extract (D3); while it is insignificantly different from MS + $100 \mathrm{~g} / \mathrm{l}$ bean sprout extract (D2) and MS + $200 \mathrm{~g} / \mathrm{l}$ bean sprout extract (D4).

\section{Discussion}

The growth and development of plantlet in tissue culture technique is influenced by the media formulation that is used. The media formulation consists of several mineral, vitamins, and organic materials. To increase the quality of particular growth of the plantlets, the addition of growth hormon or organic material in the form of plant or fruit extracts can be added.

The result of the study provides a description, showing that the addition of bean sprout extract supplement can be used to improve the quality of plaintain explant growth in the tissue culture media. The same result has been showed in the study of Amaliah and Astuti (2006), in which the addition of bean sprout extract in several consentrations gives different influence on the growth of Moth Orchid (Phalaenopsis amabilis L).

Bean sprout is sprout that emerges from green bean, containing carbohydrate, protein, $\mathrm{Ca}, \mathrm{P}, \mathrm{Fe}$, and vitamin A, B1, C, in the form of soluble compounds, so that it is easier to be absorbed by the plant (Amiliah and Astuti, 2006). By the provision of the compounds, the plaintain can grow better.

Protein can be decomposed as a nitrogen source $(\mathrm{N})$ that can fertilize the plant. The role of $\mathrm{N}$ element for soil is to stimulate the vegetative growth of the plant since it can be used as the basic material in amino acid and protein syntheses. Amino acid compound (Tryptophan) is precursor of the formation of auxin hormone which can boost the cell division so that the plant can be longer and taller (Mo'o, 1992).

Tryptophan is the most important organic substance in IAA biosynthesis process (auxin). 
According to Sriyanti and Wijayanti (1994), auxin effect may increase the osmotic pressure, enhanch the protein synthesis, boost the cell permeability toward water, and soften the cell wall, so that the water can get into the cell and increase the cell volume. In low consentration (based on the plant need), auxin can stimulate the growth of root, while with high consentration it can resist the coleoptile elongation rate (root tip) and stem (Sriyanti, 2000).

According to Sriyanti and Wijayani (1994), food stock supports the energy transfer in chemistry reaction in plant body. Phosphor is significantly requires in seedlings phase. In addition, Sriyanti (2000) said that phosphor (P) element is mostly required by the plant for the vegetative growth and to strengthen the plant part, so that the plant can be stronger. Similiarly, Mo'o (1992) said that P element will stimulate the growth of the root. Thus, it enables the bean sprout extract to be able to increase the growth of root, root number, and the plant leaf lenght.

Another element contained in bean sprout is vitamin. According to Sriyanti and Wijayani (1994), thiamin (vitamin B1) is an essencial vitamin for almost all of plant tissue culture. The function of thiamin is to boost the cell division in root meristem and act as coenzim in reaction that produce energy from carbohydrate.

The tratment of MS $+200 \mathrm{~g} / \mathrm{l}$ bean sprout extract (D4) provides leaf length, root length, and root number better than other treatments. It is due to the addition of $200 \mathrm{~g} / \mathrm{l}$ bean sprout extract (D4) into MS media that can indicate the existance of optimum compounds and nutrient in a good media. Bean sprout also contain nutrients that are useful for the banana growth; one of which is calsium. According to Sutiyoso (20013), calsium acts as cell wall, managing the permeability of the cell wall, boosting the plant growth due to the active cell division and cell extension, protein synthesis, carbohydrate transportation to the target parts, as well as in roots growing point.

Meanwhile, in MS media without bean sprout (D0) and MS + 50 g/l bean sprout (D1), it shows that plaintain wet plantlet is higher. However, it seems that the plantlet performance seems to be weaker and vigorous. This condition will cause resistence on the plantlet in aclimation phase due to the addition of protoplasma in plaintain plantlet, causing the cell wall soft and more permeable. As the result, water will easily enter the cell and make the cell bigger. Hence, it causes the plantlet wet weight higher compared to the other treatments. Unfortunately, this condition is poorly good for the plaintain plantlet development for the plantlet will be easily attacked by desease, fragile, and weaker compared to the plantlet with bean sprout extract treatment.

Furthermore, in MS without bean sprout extract (D0), it shows that the plant height and root growth components are not significantly better. It relates to the auxin and vitamin contents that are less in number, so that the plantlet roots growth becomes slower (Anonim, 2012). According to Hoflich (1995), this is due to natural auxin hormone in bean sprout that can stimulate the root cells.

\section{Conclusion}

The addition of bean sprout extract as supplement in basic media of MS (Murashige and Skoog) can increase the growth and development of plaintain $M$. paradisica L.that is bred by tissue 
culture.

The addition of bean sprout between 100-200 g/l of media provides a better effect on the plantlet height, leaf length, root length, and root number of plaintan M. paradisica $\mathrm{L}$.

\section{References}

Amaliah dan Astuti (2006). Pengaruh Konsentrasi Ekstrak Tauge dan Kacang Hijau pada Media Vacin and Went (VW) Terhadap Pertumbuhan Kecambah Anggrek Blan (Phalaenopsis amabili, L). http://id.scribd.com/doc/25831070/Pengaruh-Konsentrasi-Ekstrak-Taoge. Diakses pada tanggal 10 Oktober 2012.

Anonim.(2012). Faktor yang Mempengaruhi Pertumbuhan dan Perkembangan pada Tumbuhan.http://budisma.web.id/materi/sma/biologi-kelas-xii/faktor-yang-mempengaruhi-pe rtumbuhan-dan-perkembangan-pada-tumbuhan/. Diakses pada tanggal 20 November 2012.

Gunawan, L. W. (1992). Teknik Kultur Jaringan Tumbuhan.Depdikbud. Dirjen Pendidikan Tinggi, Pusat Antar Universitas Boiteknologi. IPB. Bogor. 165 hal.

Media Kultur Jaringan. PT. Multi Apical Consultan. Yogyakarta.

Mo'o, H. E. (1992). Pengujian Beberapa Media Sapih Sederhana dalam Budidaya Kultur Jaringan Terhadap Komponen Pertumbuhan Planlet Anggrek Dendrobium None Betawi.Skripsi. Fakultas Pertanian, Universitas Mercu Buana. Jakarta.

Pemuliaan Tanaman secara In Vitro. Universitas Gadjah Mada, Yogyakarta.

Satuhu dan Supriyadi.(1999). Pisang: Budidaya, Pengolahan, dan Prospek Dasar. Penebar Swadaya: Jakarta

Soeryowinoto, M. (1985).Budidaya Jaringan dan Manfaatnya. Fakultas Biologi, Universitas Gadjah Mada, Yogyakarta.

Sriyanti, D. H. (2000). Pembibitan Anggrek dalam Botol. Kanisius. Yogyakarta.

Sriyanti, D. H. dan A, Wijayani. (1994). Teknik Kultur Jaringan "Pengenalan dan Petunjuk Perbanyakan Tanaman Secara Vegetatif Modern”. Kanisius. Yogyakarta.

Thymann, K.V. (1935). On the plant growth hormone produced by Rhyzopus sinuis.In Leopold A.C. and Paul E Kriedermann. 1975. Plant growth and development. Second edition. Mc Graw Hill book company. 545 pp.

\section{Copyright Disclaimer}

Copyright reserved by the author(s).

This article is an open-access article distributed under the terms and conditions of the Creative Commons Attribution license (http://creativecommons.org/licenses/by/3.0/). 